УДК: 82.091

ББК: 71; 83.3(2Poc=Pyc)

A43

DOI: 10.18688/aa200-2-35

W. C. Brumfield

\title{
Confrontation in Idyllia: The Country Estate as Moral Space in Russian Literature
}

In this article I will propose that the Russian country estate (usad'ba) as a literary construct serves to create a "moral space" (moralis locus) within which the most profound existential questions are presented, examined and debated. The stage-like spatiality of the country estate - enclosed yet in proximity to the natural environment - provides an ideal setting not only for gathering the verbal antagonists but also for establishing their identity as a function of their attitude toward the presence of nature. This latter element - the presence of nature in turn summons the question of the characters' (and writers') relationship to Romanticism in $19^{\text {th }}$-century literature. It was Romanticism which elevated the human perception of Nature's transcendent harmony as a fundamental literary trope (cf. William Wordsworth). At the same time the immediate presence of nature as a productive, life-nourishing land placed the usad'ba within the intractable social problems of the peasantry and its economic plight, before and after the emancipation in 1861.

The usad'ba, therefore, presented - and confronted - Russian writers with a nexus of essential social and cultural topics woven into a fabric of varying literary norms. Writers made individual choices regarding genre and style that facilitated their representation of the rural environment. Within this environment, the actions and words of literary characters projected an immense range of attitudes - often counterposed - toward the land and the people who embodied its Russian destiny. To illuminate this counterpoint, I will provide a close reading of two works set on the country estate in the 1860s: Ivan Turgenev's Fathers and Sons (1862) and Hard Times (1865) by Vasilii Sleptsov.

My point of departure derives from the words et in Arcadia ego, usually associated with Virgil's fourth eclogue. Yet, in its precise form, the phrase appears to be the invention of Nicolas Poussin in a painting of that title, where they appear on a sarcophagus (See ex. [6]). The phrase has been subject to more than one interpretation: that death is present even in Arcadia (memento mori); or that the departed, although no longer partaking of earthly pleasures, also participated in the Arcadian idyll (See $[5 ; 9 ; 13])$. But, I would add a third possibility: the ego is that of the artist who creates our vision of Arcadia and meditates upon life and death therein.

Arcadia, which exists to this day as an administrative region in Greece, was known in the classical world as an isolated, rustic haven, the realm of simple but happy existence. Yet, as often in Poussin's landscapes, architecture in the form of a classical pavilion or temple - or more 
prosaic structures - signifies both the presence of civilization and its passing ${ }^{1}$. Paradoxically, the rustic setting in these landscapes suggests not an idyll but an evocation of conflict and the decline of civilizations - the abandoned temple.

Even the names of protagonists in $19^{\text {th }}$-century Russian prose provide subtle and complex references to a conflict within Arcadia: Arkadii Kirsanov, co-protagonist in Ivan Turgenev's Fathers and Sons; Arkadii Dolgorukii, protagonist of Dostoevskii's The Adolescent; and Irina Arkadina in The Seagull, set on a country estate. Arkadina is anything but a simple rustic, and to suggest her connection with Arcadia requires a measure of irony inherent in Chekhov's comedic sense. Arkadina's indifference to Trigorin's plea to remain at the estate (at the end of Act Three) not only implies a rejection of the Arcadian idyll (myth) but also signals a turning point leading to the decline of the estate, a tenuous refuge for shattered dreams. Indeed, the departure from Arcadian estate is a persistent motif in Chekhov's comedies (as he called them): Ivanov, Seagull, Three Sisters, Uncle Vanya (note Astrov's acerbic cry "E finita la comedia"), and Cherry Orchard. Everyone abandons the estate, symbolized by the dead seagull, the felled cherry orchard. I would also argue that the opustevshii dom serves as a metaphor for the rejection of the Romantic perception of nature's transcendent harmony.

But let us return to origins. From the latter part of the $18^{\text {th }}$ century, the concept of Arcadia was readily accepted by Russians writers. Particularly significant as a starting point is Gavriil Derzhavin's "Evgeniiu. Zhizn' Zvanskaia” (1807), which proclaims social harmony and spiritual peace as defining virtues of the country estate in contrast to the luster and vanity of St. Petersburg. Set within a benevolent natural environment, this harmony embraces all, including the peasants (enserfed), who benefit from the enlightened management of the lord of the manor. In this literary presentation of the estate, perceptions of nature console and delight. Set within the fertile land, the estate and nature are joined in an approximation of the Arcadian idyll. Derzhavin's masterpiece lays the foundation for the further literary development of the estate topos - including, ultimately, its rejection.

As $19^{\text {th }}$-century Russian literature unfolds, the country estate becomes a moral space (moralis locus) within which competing visions find their expression. The darker side is evident in Nikolai Gogol's depiction of a series of estates in Dead Souls (1842). Through satire and mordant humor, there portrayals of the estate at times approach an inversion of the Arcadian idyll, a microcosm of hell (cf. Pliushchkin).

A more ambivalent approach the Arcadian vision appears in Aleksandr Pushkin's Evgenii Onegin, which on the one hand continues the Derzhavian evocation of rural harmony in its descriptions of nature, village and country estate. Curiously, in his article "Evgenii Onegin: Et In Arcadia Ego", Mark Al'tshuller links the words "et In Arcadia Ego" to the concept of the Golden Age, which he in turn places within the very urban environment of St. Petersburg during Pushkin's time [1]. This counterintuitive reasoning leads to a suggestive association of the Arcadian idyll with the Golden Age, a motif pursued in such definitive works of art as Claude Lorrain's "Acis and Galetea" and Watteau’s "Embarkation for Cythera". These widely-

1 Russia's major acquisition of Poussin occurred in 1779, when Catherine the Great purchased Sir Robert Walpole's legendary collection, which brought to Russia many works by Poussin, as well as by Claude Lorraine, Rembrandt, Rubens, Van Dyck, et al. Among Poussin's 15 works in the Hermitage are two washes of landscapes with classical motifs. There are also major works in the Pushkin Museum in Moscow. 
known paintings were familiar to Dostoevskii and play a role in summoning the concept of the Golden Age that suffuses critical passages in The Adolescent (Arkadii contra Versilov) and further appears in Stavrogin's delirium.

But let us return to the country estate as Pushkin defines it in Evgenii Onegin.

If Pushkin, on one hand, continues the Derzhavian vision, on the other, he establishes the themes of death and rejection nested within the Arcadian setting. To take only two of the most prominent episodes - Onegin's rejection of Tat'iana within the ambience of an estate house and the duel that leads to Lenskii's' death - one sees a reversal of the concept of harmony. As noted above, this reversal can be interpreted within Poussin's "Et in Arcadia Ego". Even the tone of nature's conciliation evoked by the description of Lenskii's grave creates a sense of death within Arcadia. It can be argued that in Evgenii Onegin, Pushkin has created the motif of the abandoned estate.

Evgenii Onegin provides a basis for the central comparison in my text - between Ivan Turgenev's Fathers and Sons (1862) and Vasilii Sleptsov's short novel Hard Times (1865)2. Lenskii's lethal duel with reluctant Onegin is transformed into a parody of the duel between Pavel Kirsanov and another Evgenii, - Bazarov. And when Bazarov dies futilely from an unexpected minor infection, his country grave - at one with nature - also serves as a point of reconciliation, visited by his grieving, elderly parents. In contrast, the gentle characters of Arkadii and his betrothed Kat'ia enter their Arcadian destiny on the country estate - a destiny denied to the characters in Evgenii Onegin.

In the sardonic realism of Sleptsov's Hard Times, the duel by pistols has been replaced with a duel of words between the estate owner Shchetinin and Riazanov, his radically inclined acquaintance from student days. The concept of Idealistic radicalism in $19^{\text {th }}$-century Russian literature has generally devolved upon Turgenev's Bazarov. Yet it can be argued that Sleptsov created a clearer portrayal of the intellectual radical (intelligent) in the persona of Riazanov. The two protagonists created by Turgenev and Sleptsov serve as embodiments of social and moral values, but there are fundamental differences in the literary approaches. In each case, the country estate serves as the milieu in which defining characteristics are revealed and developed.

In his essay "Bazarov Yet Again" (Eshche raz Bazarov; 1868), Alexander Herzen writes, "This mutual interaction of people and books is a strange thing. A book takes its shape from the society that spawns it, then generalizes the material, renders it clearer and sharper, and in consequence reality is transformed" [7, p. 337]. Many of the novel's exegetes have portrayed Bazarov as a representative of radical tendencies in the sixties. I would argue that Bazarov's character is shaped to a greater degree by a literary archetype deriving from European Romanticism and delineated in Turgenev's earliest writings.

In comparing these literary "radicals" it should be noted that Sleptsov was well known for his participation in radical causes during the 1860s and had a more intimate knowledge of the radical milieu than did Turgenev. Furthermore, Sleptsov, who began his career as a writer in the early sixties, lacked the Romantic apprenticeship which had a pervasive influence on Turgenev's mature work. In both personal and literary contexts, Sleptsov presents the radical intelligent from a different perspective.

For a detailed examination of the literary and political activity of Vasilii Sleptsov, see William C. Brumfield [4]. 
The similarity between Fathers and Sons and Hard Times was first noted by Dmitrii Pisarev in an article entitled Flourishing Humanity ("Podrastaiushchaia gumannost", 1865). Pisarev characterizes Sleptsov's protagonist, Riazanov, as "one of the brilliant representatives of my beloved Bazarov type" [10, p. 53]. Both Bazarov and Riazanov are raznochintsy (the latter a priest's son), disaffected intellectuals who propose to destroy so that others may build, although neither is certain as to how the destruction will occur or who will do the building. Both represent the rise of a new class and a new militancy in Russia's educational system. Both are products of the urban intellectual milieu - although their origins link them to the provinces of central Russia ("Riazanov", "Bazarov"). Both are intruders in the country estate, which is itself beset with problems of social reform.

On this last point even the details correspond: the estate landowners in both novels Nikolai Kirsanov and Ivan Shchetinin - attempt to introduce agricultural improvements and reforms in their dealings with the peasants, but their efforts are viewed with suspicion by neighboring landowners and with indifference by the peasants (a reaction familiar to Tolstoy's repentant landowners). Kirsanov and Shchetinin are swindled by their laborers and are baffled by their ignorance, superstition, and resistance to the reform. Descriptions of poverty are frequent, particularly in Hard Times, while attempts to implement a rational system of agricultural productivity are continually frustrated. (In both works a new threshing machine, purchased at great expense, proves too heavy for local conditions.) The similarity extends to the physical setting as well: the same dilapidated church, the same peasant huts clustered in a village near a manor house with the same arbors and acacias.

Once placed in this estate setting, both protagonists are led into a situation which pits their urban radicalism against a form of gentry liberalism. Each novelist relies heavily on dialogue to develop a conflict which arises from ideological antagonism, but there is a difference in the function of these confrontations. In Hard Times they so dominate the core of the work that plot is relatively unimportant and the narrator's comments are little more than extended stage directions. In Fathers and Sons, which has a plot of greater complexity, the narrator's intrusions direct the reader's perception of events, while ideological arguments serve primarily to motivate a course of action which eventually has little to do with ideology. Nevertheless, both works begin with a similar conflict, and they present it in similar terms.

From the moment Pavel Kirsanov first hears the word "nihilist", until Bazarov's dialog with Odintsova in chapter sixteen, Turgenev's radical periodically expresses views which cannot be reconciled with the idea of social progress through gradual reform. Two passages - both in chapter ten - are particularly close to the views Riazanov will express in Hard Times. In the first Bazarov dismisses the vocabulary of liberalism (as expressed by Pavel Kirsanov): "Aristocracy, liberalism, progress, principles $<\ldots>$ if you think about it, how many foreign... and useless words!" [16, p. 48]. In the second, he makes one of the most common accusations against Russian liberalism - its inability to act:

Then we figured out that talking, always talking about our sores wasn't worth the effort, that it only led to banality and doctrinairism. We saw that even our smart ones, so-called progressive people and exposers of abuses, were fit for nothing; that we were occupied with nonsense, were harping about some sort of art, unconscious creativity, parliamentarianism, the legal profession, and the devil knows what else, while it's a question of daily bread... [16, pp. 50-51]. 
In one passage from Hard Times Riazanov develops a similar argument as he explains to Shchetinin's wife the uselessness of progressive articles she has been reading:

You see, it's all the same. You have these signs, and on them it's written 'Russian Truth' or 'White Swan'. So you go looking for a white swan - but it's a tavern. In order to read these books and understand them, you have to be practiced $\langle\ldots\rangle$. If you have a fresh mind and you pick up one of these books, then you really will see white swans: schools, and courts, and constitutions, and prostitutions, and Magna Carta, and the devil knows what else... But if you look into the matter... you'll see that it's nothing but... a carry-out joint [14, p. 83].

In the same vein Bazarov states that "at the present time, negation is the most useful action", that before construction "the ground has to be cleared" [16, p. 49], while Riazanov gives Shchetinina a paraphrase of one of his radical pamphlets: "If you want to build a temple, first take measures so that the enemy cavalry doesn't use it as a stable" [14, p. 79]. When Shchetinina asks, what is to be done, Riazanov answers: “...all that's left is to think up, to create a new life; but until then...' he waved his hand" [14, p. 148]. Riazanov's manner of expression may be earthier than Bazarov's, yet the ideas are the same. Bazarov's rage against useless talk notwithstanding, neither radical goes beyond the rhetoric of frustration.

But however similar the rhetoric, the ensuing development reveals a fundamental difference between the novels. Turgenev, it would seem, is less interested in Bazarov the nihilist (understood as a product of ideology) than in Bazarov the Romantic rebel. For by the middle of Fathers and Sons the ideological element begins to recede and it becomes clear that Bazarov's radical views, rather than determining his actions, have served to establish a position of isolation from which he can offer his challenge to the order of the universe. Turgenev has endowed his hero with a matrix of current political opinions, only to lead him toward a confrontation between his "fathomless" ego and his "intimation of mortality" - a confrontation inherent in Bazarov's aggressive determination to understand the essence of nature through a type of scientific materialism. If in his challenge Bazarov has lost a sense of oneness with nature (the talisman scene), Turgenev effects a final reconciliation which implies a Romantic view of the unity between man and nature - or a longing for that unity:

However passionate, sinning, and rebellious the heart concealed in the tomb, the flowers growing over it look at us serenely (bezmiatezhno) with their innocent eyes: they tell us not of eternal peace along, of that great peace of 'indifferent' nature; they tell us also of eternal reconciliation and of life without end... [16, p. 188].

The evidence for viewing Bazarov's nihilism as one component of a romantic image is grounded in Turgenev's own statements on the subject, particularly in his preparatory remarks for Virgin Soil (Nov', 1876). He writes that there are "Romantics of Realism", who "long for the real and strive toward it as former Romantics did toward the ideal", who seek in this reality "something grand and significant" ("nechto velikoe i znachitel'noe") [17, p. 399]. After characterizing the type as a prophet, tormented and anguished, Turgenev adds: "I introduced an element of that Romanticism into Bazarov as well - a fact that only Pisarev noticed" [17, p. 399].

This reference to the hero as a Romantic or Realism is the most explicit statement of the relation between Bazarov's faith in materialism and the Romantic spirit which informs his behavior. But that spirit is clearly defined within the novel itself - defined in part, by Bazarov's use of terms such as "romantic" and "romanticism". In chapter four, he says of the elder 
Kirsanovs: "...these elderly romantics! They develop their nervous systems to the point of irritation... and so their equilibrium is destroyed" [16, p. 20]. Commenting on the nature of love, he tells Arkadii: "Study the anatomy of the eye a bit; where does the enigmatic glance you talk about come in? That's all romanticism, nonsense, rat, art" ("khudozhestvo") [16, p. 34]. During the dispute in chapter ten the narrator remarks: "This last phrase [spoken by Arkadii] apparently displeased Bazarov; there was a flavor of philosophy, that is to say, romanticism about it, for Bazarov called philosophy, too, romanticism..." [16, p. 49].

In his presentation of Bazarov's thoughts on Odintsova, the narrator comments: "In his conversations with Anna Sergeevna he expressed more strongly than ever his calm contempt for everything romantic; but when he was alone, with indignation he recognized the romantic in himself" [16, p. 87]. And in chapter nineteen, Bazarov tells Arkadii: "...in my opinion it's better to break stones on the road than to let a woman gain control over even the end of your little finger. That's all..." Bazarov was on the point of uttering his favorite word, 'romanticism', but he checked himself and said 'nonsense'" [16, p. 104].

Pisarev is very much to the point when he says, in an 1862 article entitled Bazarov: "Pursuing romanticism, Bazarov with incredible suspicion looks for it where it has never even existed. Arming himself against idealism and smashing its castles in the air, he at times becomes an idealist himself..." [15, p. 27]. Indeed, Bazarov's path to self-knowledge (and spiritual crisis) is associated with the developing awareness of "the romantic within himself", however contemptuously he may react to that element.

Bazarov, of course, does not use words such as "romanticism" in a specifically literary sense. And Petr Pustovoit has noted that Turgenev's application of the terms "romantic" and "romanticism" in his critical writings often refers to a "romantic" disposition rather than to Romanticism as a literary method [11, p. 259, 272]. But, from a structural point of view, the two are inextricably connected: the literature and rhetoric of Romanticism provide the model for this romantic disposition ${ }^{3}$. In fact, the model is delineated in Turgenev's work well before Fathers and Sons. In a review of Vronchenko's translation of Faust, Turgenev describes the Romantic hero in the following terms:

He becomes the center of the surrounding world; he... does not submit to anything, he forces everything to submit to himself; he lives by the heart, but by his own, solitary heart not another's - even in love, about which he dreams so much; he is a romantic, and romanticism is nothing more than the apotheosis of personality ["apofeoz lichnosti"]. He is willing to talk about society, about social questions, about science; but society, like science, exists for him - not he for them [15, p. 202].

Much in this description could well be applied to Bazarov: the last sentence is reminiscent of his outburst against concern for the estate peasants' well-being in the face of his own inevitable death, while the phrase "apotheosis of personality" identifies one of the dominant motifs in Bazarov's character. In chapter ten, Pavel Petrovich remarks Bazarov's "almost Sa-

$3 \quad$ Iurii Mann applies such a structural approach to Romanticism in his work The Poetics of Russian Romanticism [8]. Choosing "artistic conflict" ("Romantic conflict") as his basic structural category [8, p.15], he later writes: "We have said that the Romantic method of dealing with the social theme is to introduce it into a Romantic conflict. To be more precise: the Romantic method of dealing with the social consists in the fact that the latter becomes a motivating force for alienation" [8, p. 264]. 
tanic" pride [16, p. 52], while Arkadii, in chapter nineteen, notices "the fathomless depths of Bazarov's conceit" [16, p. 102] and asks him whether he considers himself a god. Whatever the difficulties in establishing a typology for homo romanticus, the passage quote above suggests that in his commentary on Faust, Turgenev presented an interpretation of the Romantic hero which reached its culmination in the creation of Bazarov.

In view of these antecedents, it would seem that the verbal conflict between Bazarov and Pavel Kirsanov is an antagonism not so much between the idealistic liberal of the forties and the materialistic radical of the sixties, as between two "generations" of Romantics - both derived from variations of Romanticism prevalent in the thirties and forties. This common element in Turgenev's conception of Bazarov and Kirsanov has not been sufficiently acknowledged, although it is developed through an extensive system of parallels in their characterization as well as their fate. Each is passionate in his defense of certain principles, abstractions, and ideals (Bazarov's "materialism" is just as idealistic as Kirsanov's liberalism). But for all their apparent dedication to an ideological position, each is led to believe that his life is without purpose.

To be sure, there is a difference in their expression of this belief: Kirsanov's resignation as opposed to the anger and defiance of Bazarov's metaphysical nihilism. Yet it must be emphasized that both expressions are developed not within an urban milieu - which hovers in the background of the characters' respective pasts - but in the setting of the country estate. For both Kirsanov and Bazarov, Turgenev motivates the crisis with a passionate affair that represents his conception of the incomprehensible power of love - love unattainable, which can end only in death. Pavel Kirsanov, shattered by his attraction to the "mysterious" Princess R. (chapter seven) enters a period of decline on the country estate in which his former hopes and ambitions are abandoned.

On the estate, Kirsanov is consigned to an existence that has all the appearance of a romantic cliché: "Ladies considered him an enchanting melankholik, but he did not associate with ladies" [16, p. 225]. And Bazarov claims to see through the cliché. After the account of Kirsanov's life (ostensibly told by Arkadii) Bazarov responds: "And what about these mysterious relations between a man and a woman? We physiologists know what such relations are. Study the anatomy of the eye..." [16, p. 226]. But Kirsanov's affair is merely a prelude to Bazarov's confrontation with Odintsova, during which Turgenev will invest the cliché with a pathos appropriate to his hero's strength. Both Bazarov and Kirsanov die in the course of the novel; but Kirsanov, trapped within his image of fatal passion, is granted only a lingering death in life (see the final lines of chapter twenty-four). Bazarov, however, transcends the motif of destructive love by the strength of a rebellion which reflects the egocentric Romantic anguish so imperfectly realized in Steno.

Turgenev has chosen the country estate as a means to isolate Bazarov and Pavel Kirsanov within an intensely subjective, individual crisis that has little direct relation to an ideological dispute between opposing generations. Indeed, the entire notion of generational conflict in Fathers and Sons is open to question. It is often assumed that the title implies sons against fathers, yet the Kirsanovs are reconciled at the end of the novel and the affection between Bazarov and his parents is beyond doubt. Furthermore, Pavel Kirsanov and Bazarov reach a tenuous reconciliation of their own, following the duel which again reveals the Romantic principle in both - Bazarov's rationalizations notwithstanding. Whatever the initial opposi- 
tion (based on role stereotypes - youth rebelling against its elders), it is affinity between the generations that defines the basic pattern of relations between fathers and sons (Bazarov's father shouting at the end of chapter twenty-seven, "I rebel, I rebel" [16, p. 184].

Rather, the book's irreconcilable conflict is surely between the two sons, and it is all the deeper - and more subversive - for not being expressed in ideological terms. Arkadii, whose political views are dismissed early in the novel, is representative of the "honest consciousness", one who accepts his role within the family and its process of biological continuity. Bazarov, well aware of his companion's apostasy ("You're not made for our bitter, rough, lonely existence" [16, p. 380]), consigns him to his domestic, jackdaw happiness (the banality of the family), thus intensifying the isolation so necessary for his own image. Indeed, Arkadii has replaced his "radical" opinions with a desire to turn a profit on the family estate - and in so doing, illustrates Turgenev's statement in the letter to Konstantin Sluchevskii: "My entire story is directed against the gentry as a progressive class" [18, p. 57]. As Arkadii and Katia enter Arcadia in fulfillment of roles appropriate to pastoral comedy, Bazarov, the Romantic radical, is left to his tragic destiny. Like Rudin, he is remembered by the happy at their feast (discreetly, to be sure). But also like Rudin, he can have no place with the settled and unrebelling.

In comparison with Turgenev's romanticized view of revolt, Sleptsov takes a prosaic approach to radicalism, as presented in observations of life on the country estate. One could point to an element of the Romantic in Riazanov - like Bazarov, a rebel and prey to the ressentiment which accompanies his rebellion (that wave of the hand). But Sleptsov undercuts the element by his laconic narrative tone as well as by the structure of a plot which can be reduced to the simplest of outlines: Riazanov, a radical intelligent escaping Petersburg in the wake of a new period of repression (1863), arrives at the estate of his university acquaintance, Shchetinin, now married and settled into what he hope will be the morally and financially satisfying role of enlightened landowner. Riazanov and Shchetinin engage in a series of arguments during which the radical attempts to demolish the liberal's belief in gradual social progress through reform. But the focus of the novel eventually shifts to Shchetinin's wife.

Under the sway of Riazanov's nihilistic opinions, Shchetinina can no longer accept what she now sees as her husband's impotent liberalism. She decides to abandon her role as benevolent estate mistress and devote herself to another cause. Yet, when she turns to Riazanov for the emotional and moral support to sustain her in this decision, she is rebuffed. In an intertwining of sexual and ideological elements characteristic of the relations within this ménage à trois, Riazanov rejects her sexual advances as well as her desire to aid him in his vaguely defined radical activity. Shchetinina, however, perseveres in her resolve to leave the estate for Petersburg, where she will attempt to join the ranks of the "new people", despite Riazanov's dim view of this fashionable radicalism (an echo, perhaps, of Bazarov's attitude toward Sitnikov and Kukshina).

The novel ends in a standoff. Shchetinin takes refuge in his reform projects, and a liberated Maria Shchetinina goes to Petersburg in search of her cause. Riazanov, committed to a distant and uncertain revolution, leaves the estate with his one trophy, a deacon's son, who intends to enroll in a provincial school against his father's wishes (another raznochinets activist in the making). Sleptsov has clarified relations between the characters only to leave them on the threshold of other ambiguities. In a literary variant of his own nihilism he offers no 
positive solution to the questions the work raises, nor does he imply that his characters are capable of finding such solutions.

It should be clear then that Sleptsov, in contrast to Turgenev, adheres to the ideological conflict posed at the beginning of the work, while avoiding a romanticized image of the radical which would focus attention of character rather than ideology. Such an approach has implications not only for the significance of the protagonist, but also for the development of the novel. For while Turgenev directs his work to a consideration of Bazarov and his fate, Sleptsov, focusing on the problem of radical response during a period of "hard times", begins where Turgenev leaves off: in the liberal gentry's Arcadia. In Shchetinin, Riazanov confronts not a Pavel Kirsanov but his own contemporary, a new type of liberal - practical (or so he thinks), optimistic, willing to accept emancipation reforms with the understanding that they should be made to work in his own interests. The question is will they? And at what cost to the peasants who supply the labor?

It is essential to note that Turgenev and Sleptsov perceive the question of reform with the context of the countryside. Turgenev, in a final, brief gesture of concern with social issues indicates that there will be problems in adjusting to the reforms (i.e. land reforms) but couples his remark with references to the Kirsanov's growing prosperity on the country estate. Beyond this such problems do not interest him, because they provide no scope for the greater struggle which is his true concern. Bazarov merely dismisses Arkadii's new role as benevolent landowner, he does not challenge it. The Romantic rebel is not concerned with the details or pretensions of land reform, and he does not return to accuse Arkadii of hypocrisy in his dealings with the peasants - indeed, he cannot return. His isolation must be maintained in the interests of a conclusion beyond specific considerations of politics and ideology.

The preceding comparison has examined relations between radicalism and literary archetype as presented in the setting of the country estate. Sleptsov created a novel that reflects and comments on his views as a radical intellectual. In presenting a form of populist radical ideology peculiar to the 1860s (with its focus on land reform and justice for the peasantry), Sleptsov shows little tendency to idealize radical proponents. As a result, that Sleptsov offers a radical perspective or critique without transforming his characters into advocates of a simplistic, utopian solutions in the manner of Nikolai Chernyshevskii.

Turgenev's achievement is of a different order in which the role of ideology is more tenuous. His political and philosophical views and his ambivalence toward Bazarov have received much attention [12; 2; 3]; but efforts to interpret Fathers and Sons solely in terms of the "liberal predicament" or a specific philosophical system are inadequate. It has been noted that Turgenev's correspondence during the latter part of 1860 contains frequent references to a sense of depression. Although this is not an uncommon mood in his writings, one such letter (to Afanasii Fet) suggests a link between this despondency and his irritation with the young critics then in control of Sovremennik who wished to consign their elders to oblivion [19, pp. 60-61]. It may well be that Bazarov represents Turgenev's attempt to come to terms with the radical spirit which both fascinated and repelled him.

But in doing so Turgenev returned to a problem which had occupied him at the earliest stages of his literary career: the challenge and the ressentiment of the Romantic hero, the apotheosis of self. When Antonovich labels Bazarov a "caricature" trying to imitate a demonic 
or Byronic nature, and Turgenev, in a letter to Ludwig Pietsch, writes, "ich den ganzen Kerl viel zu heldenhaft - idealistisch [read "romantisch"] aufgefasst habe" [20, p. 223], both are admitting the same thing from different points of view. Bazarov is not a caricature, but it is equally true that Turgenev attached ideological positions to a Romantic archetype and then submerged them in other, literary and metaphysical concerns inherent in the type.

In his more measured, realistic approach, Sleptsov suggests a fading of the Arcadian concept in late $19^{\text {th }}$-century Russian literature. If Lev Tolstoi reveals an ambivalence toward the Arcadian idyll in Anna Karenina (1878), where the estate again serves a moralis locus, he adopted an increasingly darker, critical vision toward the end of his life, culminating in his final, fateful flight from Iasnaia Poliana. As noted above, Chekhov's plays imply a rejection or abandonment of Arcadia. One can also note the elegiac, fading depiction of the estate in Russian art: for example, Vasilii Maksimov's "All Past" (1889) and Viktor Borisov-Musatov's "Ghosts" (1903) - Arcadia as a symbolist world of dreams.

With the advent of the communist regime, the usad'ba as literary trope assumed a distant, generally negative character. Yet even in this forbidding context, the usad'ba resumed its function as a moral space in the most unlikely of contexts. In his novel $V$ kruge pervom Aleksandr Solzhenitsyn places his primary characters within the enclosed, guarded space of a sharashka situated at the former Marfino estate near Moscow. While the soul-crushing GULAG system might seem an utter perversion of the Arcadian idyll, the prisoners in Solzhenitsyn's historically accurate portrayal indeed lead a relatively privileged existence ("in the First Circle of Dante's Inferno"). In Solzhenitsyn's masterful treatment, moral characteristics of the literary topos return as the characters dialogically confront each other within an estate ambience monstrously distorted. Yet even here the estate is abandoned when the main protagonist, Gleb Nerzhin, rejects further complicity with the relatively privileged sharashka regime and returns to a lower circle of GULAG hell.

Through it all, there remains a longing in Russian culture for the Arcadian myth as embodied in the country estate. The usad'ba is an essential part of cultural mythology, deeply bound through literature to the most fundamental of myths - The Fall and Expulsion from Paradise. In its choice of the usad'ba as setting, the classics of $19^{\text {th }}$-century Russian literature remind of a persistent bond to the Arcadian vision: nature, the land, the country refuge. Et in Arcadia... ego.

\section{References}

1. Al'tshuller M. 'Evgenii Onegin': Et in Arcadia Ego. Pushkin: Issledovaniia i materialy (Pushkin: Research and Materials). St. Petersburg, Nauka, 2004, pp. 218-233 (in Russian).

2. Batiuto A. I. Turgenev - romanist (Turgenev as Novelist). Leningrad, Nauka Publ., 1972. 394 p. (in Russian).

3. Berlin I. Fathers and Children: Turgenev and the Liberal Predicament. Oxford, Clarendon Press Publ., $1970.63 \mathrm{p}$.

4. Brumfield W. C. Slepcov Redivivus. California Slavic Studies, vol. 9. Berkeley, University of California Press, 1976, pp. 27-70.

5. Braider Ch. Refiguring the Real: Picture and Modernity in Word and Image, 1400-1700. Princeton, Princeton University Press, 2015. 338 p.

6. Granjard H. Ivan Tourguenev et les courants politiques et sociaux de son temps. Paris, Institut d'etudes slaves, 1966. 506 p. (in French). 
7. Herzen A. I. Eshche raz Bazarov (Bazarov Yet Again). Sobranie sochinenii (Works in 30 vols.), vol. 20, book 1. Moscow, Gorky Institute of World Literature Academy of Sciences USSR, Publ., 1960, pp. 335-350 (in Russian).

8. Mann Iu. Poetika russkogo romantizma (The Poetics of Russian Romanticism). Moscow, Nauka Publ., 1976. $375 \mathrm{p}$.

9. Panofsky E. "Et in Arcadio ego": Poussin and the Elegaic Tradition. Panofsky E. Meaning in the Visual Arts. Harmondsworth, Penguin Publ., 1970, pp. 340-367.

10. Pisarev D. I. Sochineniia (Works, in 4 vols.), vol. 1. Moscow, Goslitizdat Publ., 1955. 388 p. (in Russian).

11. Pustovoit P. G. Romanticheskoe nachalo v tvorchestve Turgeneva (The Romantic Principle in Turgenev's Work. Kuleshov V. I. et al (eds.). Romantizm v slavianskikh literaturakh (Romanticism in Slavic Literatures: Collection of Articles). Moscow, Lomonosov Moscow State University Publ., 1973, pp. 258-277. (in Russian).

12. Pustovoit P. G. Roman I. S. Turgeneva "Ottsy i deti": Kommentarii (I. S. Turgenev's Novel "Fathers and Sons": Commentaries). Moscow, Prosveshchenie Publ., 1991. 191 p. (in Russian).

13. Scolnicov H. Meeting one's Death in Arcadia. Analecta Husserliana, vol. 84, pp. 249-261.

14. Sleptsov V. A. Trudnoe vremia (Hard Times). Sleptsov V. A. Sochineniia (Works in 2 vols.), vol. 2. Moscow, Goslitizdat Publ., 1957, pp. 3-162. (in Russian).

15. Turgenev I. S. Faust, a Tragedy by Goethe, translation. 1844. Turgenev I. S. Polnoe sobranie sochinenii i pisem (Complete Works and Letters in 30 vols., Works in 12 vols.), vol. 1. Moscow, Nauka Publ., 1978, pp. 195-235 (in Russian).

16. Turgenev I. S. Fathers and Sons. Polnoe sobranie sochinenii i pisem (Complete Works and Letters in 30 vols.), vol. 7. Moscow, Nauka Publ., 1981, pp. 7-187 (in Russian).

17. Turgenev I. S. Nov'. Podgotovitenye materialy. Turgenev I. S. Polnoe sobranie sochinenii i pisem (Complete Works and Letters in 30 vols.), vol. 9. Moscow, Nauka Publ., 1982, pp. 399-422 (in Russian).

18. Turgenev I. S. Polnoe sobranie sochinenii i pisem (Complete Works and Letters in 30 vols., Letters in 18 vols.), vol. 5. Moscow, Nauka Publ., 1988. 640 p. (in Russian).

19. Turgenev I. S. Polnoe sobranie sochinenii i pisem (Complete Works and Letters in 30 vols., Letters in 18 vols.), vol. 6. Moscow, Nauka Publ., 1989. 366 p. (in Russian).

20. Turgenev I. S. Polnoe sobranie sochinenii i pisem (Complete Works and Letters in 30 vols., Letters in 18 vols.), vol. 9. Moscow, Nauka Publ., 1995. 478 p. (in Russian).

Title. Confrontation in Idyllia: The Country Estate as Moral Space in Russian Literature

Author. William Craft Brumfield - Ph. D., professor of Slavic studies. Tulane University, Department of Germanic and Slavic Studies, 305 Newcomb Hall 1229 Broadway, New Orleans, Louisiana 70118, USA. william.brumfield@gmail.com

Abstract. The Latin phrase "Et in Arcadia ego" has been interpreted as referring both to the presence of man in an idyllic place and to the presence of death in that same space. The article applies this ambiguous treatment to the Russian country estate as a place of moral conflict in the novel Hard Times by V. A. Sleptsov and I. S. Turgenev's Fathers and Sons. Their interpretation requires an understanding of both the setting of the estate within the natural environment and its socio-cultural status linked to the theme of social justice in Russian during the $19^{\text {th }}$ and early $20^{\text {th }}$ centuries. The article demonstrates that a crucial function of the Russian country estate as a literary topos is the creation of a moral space (moralis locus) within which profound existential questions are posed and discussed. The stage-like spatiality of the country estate - enclosed yet in proximity to the natural environment - provides an ideal setting not only for gathering the verbal antagonists but also for establishing their identity as a function of their attitude toward the presence of nature. This latter element - the presence of nature - in turn summons the question of the characters' (and writers') relationship to Romanticism in $19^{\text {th }}$-century literature. It was Romanticism which elevated the human perception of Nature's transcendent harmony as a fundamental literary trope. At the same time, the immediate presence of nature as a productive, life-nourishing land situated the usad'ba in the midst of the intractable social problems of the peasantry and its economic plight, before and after the emancipation in 1861 .

Keywords: estate text, moralis locus, Arcadia, nature, countryside, moral conflict, ideology, Vasilii Sleptsov, Ivan Turgenev

Название статьи. Противостояние в идиллии: усадьба как locus moralis в русской литературе Сведения об авторе. Брумфилд, Уильям Крафт - Ph. D., профессор славистики. Тулейнский 
университет, 305 Newcomb Hall 1229 Broadway, 70118, Новый Орлеан, Луизиана, США. william.brumfield@gmail.com

Аннотация. Крылатую латинскую фразу Et in Arcadia ego обычно относят как к присутствию человека в идиллическом месте, так и к присутствию смерти в этом же пространстве. В статье раскрывается неоднозначное отношение к русской усадьбе как месту морального конфликта в повести «Трудное время» В. А. Слепцова и романе «Отцы и дети» И. С. Тургенева. Подобная интерпретация требует осмысления как положения усадьбы в природной среде, так и её социокультурного статуса, связанного с темой социальной справедливости в России в XIX - начале XX в. Показано, что важнейшей функцией русской усадьбы как литературного топоса является создание «морального пространства", в котором ставятся и обсуждаются глубокие экзистенциальные вопросы. Сценический простор загородного поместья обеспечивает идеальную обстановку для столкновения идейных противников и для их идентификации в зависимости от отношения к окружающей природе. Присутствие природы поднимает вопрос об отношениях персонажей (и авторов) с романтизмом в литературе XIX в. Именно в романтизме восприятие таинственной гармонии Природы становится фундаментальным литературным тропом, передающим душевное состояние героя. В то же время непосредственное присутствие природы как продуктивной, питающей жизнь земли поставило усадьбу в центр труднопреодолимых социальных проблем крестьянства и его экономического положения до и после освобождения в 1861 г.

Ключевые слова: усадебный текст, нравственный локус, Аркадия, природа, деревня, моральный конфликт, идеология, В. А. Слепцов, И. С. Тургенев 